\title{
Perbandingan Kemampuan Literasi Matematis Siswa SMP Negeri 8 Kendari Antara Yang Diajar Dengan Model Pembelajaran Inkuiri Terbimbing Dan Yang Diajar Dengan Model Pembelajaran Konvensional
}

\author{
(Comparison Of Ability Mathematical Literacy Of SMP Negeri 8 Kendari Student Between \\ Taught With Guided Inquiry Learning Model And Taught By \\ Conventional Learning Model)
}

\author{
Ramlin $^{1}$, Kodirun $^{2}$, Kadir $^{2}$, Salim $^{3}$ \\ ${ }^{1}$ Alumnus Jurusan Pendidikan Matematika FKIP Universitas Halu Oleo \\ ${ }^{2}$ Dosen Pendidikan Matematika FKIP dan PPS Universitas Halu Oleo \\ ${ }^{3}$ Dosen Pendidikan Matematika FKIP Universitas Halu Oleo; Co-author: salimpsa@gmail.com
}

\begin{abstract}
Abstrak: Penelitian ini bertujuan untuk membandingkan kemampuan literasi matematis siswa. Populasi dalam penelitian ini adalah seluruh siswa kelas VIII SMP Negeri 8 Kendari yang terdiri dari enam kelas paralel dan satu kelas khusus. Teknik pengambilan sampel dalam penelitian ini dilakukan dengan purposive sampling. Teknik pengumpulan data dilakukan dengan pemberian instrumen penelitian berupa lembar observasi dan instrumen tes kemampuan literasi matematis berbentuk tes uraian. Teknik analisis data menggunakan statistik deskriptif dan statistik inferensial. Berdasarkan hasil analisis data dan pembahasan diperoleh kesimpulan. (1) Rata-rata kemampuan literasi matematis siswa setelah diajar dengan model pembelajaran inkuiri terbimbing sebesar 53,06 dari total skor 100. (2) Rata-rata kemampuan literasi matematis siswa setelah diajar dengan model pembelajaran konvensional sebesar 46,89 dari total skor 100. (3) kemampuan literasi matematis siswa yang diajar dengan model pembelajaran inkuiri terbimbing tidak berbeda signifikan dengan kemampuan literasi matematis siswa yang diajar dengan model pembelajaran konvensional.
\end{abstract}

Kata kunci: Kemampuan Literasi Matematis, Model Pembelajaran Inkuiri Terbimbing and Model Pembelajaran konvensional.

\begin{abstract}
This study aims to compare students' mathematical literacy skills. The population in this study is all students of class VIII SMP Negeri 8 Kendari consisting of six parallel classes and one special class. The sampling technique in this research is done by purposive sampling. Data collection technique is done by giving the instrument of research in the form of observation sheet and test instrument of mathematical literacy ability in the form of description test. Data analysis techniques use descriptive statistics and inferential statistics. Based on the results of data analysis and discussion obtained conclusion. (1) The average ability of students' mathematical literacy after being taught with guided inquiry learning model is 53,06 from total score 100. (2) Average ability of student's mathematical literacy after teaching with conventional learning model equal to 46,89 from total score 100 (3) the mathematical literacy ability of students who were taught by guided inquiry learning model did not differ significantly with the students' mathematical literacy skills taught by conventional learning model.
\end{abstract}

Keywords: The ability of mathematical literacy, Learning Model Inquiry Guided and Learning Model Conventional.

\section{PENDAHULUAN}

Pendidikan merupakan suatu cara pembentukan kemampuan manusia dalam pembangunan bangsa serta menjamin kelangsungan hidup bagi setiap manusia. Hal ini sejalan dengan yang dikemukakan

Mahdiansyah (2014: 454), pendidikan merupakan sarana untuk pencegahan resiko, serta alat yang dapat membantu meningkatkan kualitas hidup manusia secara berkelanjutan. Hal ini menuntut 
pemerintah Indonesia melalui Departemen Pendidikan Nasional untuk melakukan evaluasi ke luar dengan cara mengikuti berbagai jenis program penilaian (assessment) proses pendidikan. Salah satunya ialah dengan terlibat dalam Program for International Student Assesment (PISA) dan Trends in International Mathematics and Science Study (TIMSS). Keterlibatan ini dapat menjadi rujukan dalam memperbaiki kualitas pendidikan di Indonesia agar sumber daya manusianya dapat bersaing secara global dan tidak tertinggal dengan negara-negara lain. PISA merupakan studi internasional yang salah satu kegiatannya mengukur kemampuan matematika siswa usia 13-15 tahun (setara dengan Kelas VII - X) di negara-negara yang terlibat dalam studi tersebut.

Tujuan pembelajaran matematika di Indonesia termuat dalam Badan Standar Nasional Pendidikan (BSNP, 2006) yang termuat dalam standar isi tertulis, tujuan mata pelajaran matematika tingkat SMP/MTs agar peserta didik memiliki kemampuan sebagai berikut.

1. Memahami konsep matematika, menjelaskan keterkaitan antar konsep atau algoritma, secara luwes, akurat, efisien dan tepat dalam pemecahan masalah.

2. Menggunakan penalaran pada pola dan sifat, melakukan manipulasi matematika dalam membuat generalisasi, menyusun bukti atau menjelaskan gagasan dan pernyataan matematika.

3. Memecahkan masalah yang meliputi kemampuan memahami masalah, merancang model matematika, menyelesaikan model dan menafsirkan solusi yang diperoleh.

4. Mengomunikasikan gagasan dengan simbol, tabel, diagram, atau media lain untuk memperjelas keadaan atau masalah.

5. Memiliki sikap menghargai kegunaan matematika dalam kehidupan yaitu memiliki rasa ingin tahu, perhatian, dan minat dalam mempelajari matematika, serta sikap ulet dan percaya diri dalam pemecahan masalah.

Apabila dicermati, dalam tujuan mata pelajaran matematika tersebut terlihat bahwa kurikulum 2006 yang disusun sudah memperhatikan aspek pengembangan literasi matematis. Literasi matematis adalah kemampuan seseorang untuk merumuskan, menerapkan dan menafsirkan matematika dalam berbagai konteks, termasuk kemampuan melakukan penalaran secara matematis dan menggunakan konsep, prosedur dan fakta untuk menggambarkan, menjelaskan atau memperkirakan fenomena atau kejadian (OECD, 2010). Dengan demikian, pengetahuan dan pemahaman tentang konsep matematika sangatlah penting, tetapi lebih penting lagi adalah kemampuan untuk mengaktifkan literasi matematis itu untuk memecahkan permasalahan yang dihadapi dalam kehidupan sehari-hari (Setiawan, 2014: 245). Literasi yang dimaksud dalam penelitian ini adalah kemampuan individu untuk merumuskan, mengfomulasikan, menerapkan serta menafsirkan matematika dalam berbagai konteks dan situasi masalah.

Literasi matematis PISA (Kemendikbud, 2015: 18) merupakan kemampuan seseorang untuk memformulasi, menerapkan dan menginterpretasikan matematika pada beragam konteks dan situasi masalah. Termasuk bernalar matematika, menggunakan konsep matematika, prosedur, fakta dan alat bantu matematika untuk mendeskripsikan, menjelaskan dan memprediksi fenomena.

Indikator kemampuan literasi matematis yang digunakan dalam penilaian proses matematika dalam PISA adalah (OECD, 2010):

a) Komunikasi (Communication)

b) Matematisasi (Mathematizing)

c) Representasi (Representation) 
d) Penalaran dan Argumen (Reasoning and Argument)

e) Merumuskan strategi untuk memecahkan masalah (Devising Strategies for Solving Problems)

f) Menggunakan bahasa simbolik, formal, dan teknik, serta operasi (Using symbolic, formal, and technical language, and operations)

g) Menggunakan alat-alat matematika (Using Mathematical Tools)

Kemampuan literasi matematis terdiri atas 6 tingkatan (Level) yang berjenjang. Adapun keenam tingkatan (level) tersebut, secara lebih rinci sebagai berikut (Johar, 2012: 8-10):

a. Level 6

Para siswa dapat melakukan konseptualisasi dan generalisasi dengan menggunakan informasi berdasarkan modeling dan penelaahan dalam suatu situasi yang kompleks. Mereka dapat menghubungkan sumber informasi berbeda dengan fleksibel dan menerjemahkannya.

b. Level 5

Para siswa dapat bekerja dengan model untuk situasi yang kompleks, mengetahui kendala yang dihadapi, dan melakukan dugaan-dugaan. Mereka dapat memilih, membandingkan, dan mengevaluasi strategi untuk memecahkan masalah yang rumit yang berhubungan dengan model ini..

c. Level 4

Para siswa dapat bekerja secara efektif dengan model dalam situasi yang konkrit tetapi kompleks. Mereka dapat memilih dan mengintegrasikan representasi yang berbeda, dan menghubungkan dengan situasi nyata. Para siswa pada tingkatan ini dapat menggunakan keterampilannya dengan baik dan mengemukakan alasan dan pandangan yang fleksibel sesuai dengan konteks.

d. Level 3
Para siswa dapat melaksanakan prosedur dengan baik, termasuk prosedur yang memerlukan keputusan secara berurutan. Mereka dapat memilih dan menerapkan strategi memecahkan masalah yang sederhana.

e. Level 2

Para siswa dapat menginterpretasi dan mengenali situasi dalam konteks yang memerlukan inferensi langsung. Mereka dapat memilih informasi yang relevan dari sumber tunggal dan menggunakan cara representasi tunggal.

f. Level 1

Para siswa dapat menjawab pertanyaan yang konteksnya umum dan dikenal serta semua informasi yang relevan tersedia dengan pertanyaan yang jelas.

Pentingnya literasi matematis ini, ternyata belum diikuti dengan prestasi siswa Indonesia di mata dunia. Penguasaan literasi matematis siswa Indonesia jauh dari yang diharapkan. Hal ini ditunjukkan melalui hasil survei internasional PISA yang diunggah oleh TIM PISA Indonesia, kemampuan siswa usia 13-15 tahun pada jenjang pendidikan menengah dalam bidang matematika khususnya literasi matematis masih lemah. Pertama, tahun 2000 diikuti oleh 41 negara, Indonesia berada pada urutan ke39 pada kemampuan literasi matematis. Kedua, tahun 2003 diikuti oleh 40 negara, Indonesia berada pada urutan ke-38 pada kemampuan literasi matematis. Ketiga tahun 2006 diikuti oleh 57 negara, Indonesia berada pada urutan ke-50 pada kemampuan literasi matematis. Keempat, tahun 2009 diikuti oleh 65 negara, Indonesia berada pada urutan ke-61 pada kemampuan literasi matematis (Budiono, 2014: 8). Kelima, pada tahun 2012, menempatkan Indonesia pada peringkat 64 dari 65 negara (OECD, 2013). Keenam pada tahun 2015, menempatkan Indonesia pada peringkat 69 dari 76 negara (Gurria, 2015). 
Data tentang gambaran kemampuan literasi matematis siswa SMP Negeri di Sulawesi Tenggara tingkat Nasional secara khusus memang belum ada. Informasi yang ada hanya sebatas gambaran kemampuan literasi matematis SMP Negeri di Sulawesi Tenggara seperti kemampuan literasi matematis siswa SMP Negeri di Kota Raha oleh Mia Siswowijoyo. Berdasarkan hasil penelitiannya diperoleh bahwa rata-rata kemampuan literasi matematis siswa SMP Negeri di Kota Raha masih mencapai nilai di bawah 50\% untuk masing-masing tingkatan level pada soal tipe PISA dan secara rata-rata siswa hanya mampu menyelesaikan soal di bawah $50 \%$ untuk keseluruhan soal. Hal ini serupa dengan penelitan yang dilakukan oleh Nur Holis di Kabupaten Konawe yang memberikan gambaran yang sama bahwa rata-rata kemampuan literasi matematis siswa SMP Negeri di kabupaten Konawe juga masih sangat rendah. Capaian kemampuan literasi matematis siswa terjadi di SMP Negeri 1 Sampara dengan rerata skor 12,6. Adapun skor terendah dicapai siswa SMP Negeri 2 Bondoala dengan rerata skor 2,46 dari total skor ideal 100. Hal ini sangat ironis mengingat matematika ternyata belum menjadi salah satu mata pelajaran yang digemari siswa di Indonesia terutama di Sulawesi Tenggara. Padahal seharusnya matematika adalah pelajaran yang sangat menarik, karena aplikasi matematika hampir setiap saat dipakai dalam kehidupan sehari-hari.

Berdasarkan hasil wawancara peneliti dengan guru matematika kelas VIII yang dilakukan di SMP Negeri 8 Kendari diperoleh bahwa kemampuan siswa yang masih rendah yaitu kemampuan menyelesaikan soal yang kontekstual, mengunakan konsep matematika, menafsirkan matematika dalam kehidupan sehari-hari serta menjelaskan keterkaitan konsep dalam matematika. Sejalan dengan ini, berdasarkan tes awal soal kemampuan literasi matematis pada materi persamaan linear satu variabel yang di berikan kepada seluruh siswa kelas VIII yang berdistribusi sebanyak tujuh kelas yang terdiri satu kelas khusus dan enam kelas paralel, diperoleh nilai rata-rata kemampuan literasi matematis kelas VIII1, VIII2, VIII3, VIII4, VIII5, VIII6, dan VIII7 secara berturut-turut adalah 22,66, $17,62,13,68,17,65,17,76,13,1$, dan 13,53. Merujuk pada tes awal tersebut, dapat di simpulkan bahwa kemampuan literasi matematis siswa SMP Negeri 8 Kendari masih tergolong sangat rendah.

Melihat dari fakta di atas, rendahnya kemampuan literasi matematis siswa ini disebabkan oleh faktor siswa dan faktor guru. Faktor siswa: (1) siswa terbiasa pula menghafal konsep-konsep matematika yang penting, sementara siswa dituntut untuk menguasai berbagai bidang ilmu yang pada akhirnya siswa menjadi lupa dengan apa yang telah dihafalkannya, (2) siswa senantiasa tidak mengetahui manfaat dalam belajar matematika dalam berbagai bidang dan tidak tau bagaimana peran matematika dalam kehidupan. Konsep matematika hanya diperoleh dari guru, sehingga pengetahuan tentang konsep-konsep penting tersebut hanya lewat begitu saja namun tidak tertanam dalam memori jangka panjang siswa. Faktor guru: (1) guru tidak melatih siswa untuk menemukan sendiri pengetahuan maupun konsep-konsep matematika, sehingga pada saat diberikan soal-soal tentang pemecahan masalah atau penalaran siswa kebingungan mau dikerjakan seperti apa atau konsep-konsep apa saja yang seharusnya digunakan, (2) guru terbiasa hanya menerapkan model pembelajaran konvensional. Guru juga tidak terbiasa memberikan soal-soal penemuan. Selain itu, guru kurang memberikan bimbingan dalam pembelajaran khususnya terkait penemuan konsep matematika yang penting. Padahal pengetahuan dan pemahaman konsep tentang matematika akan lebih baik jika 
siswa dibimbing dan diarahkan bagaimana cara mendapat konsep tersebut.

Alternatif model pembelajaran yang dapat digunakan untuk persoalanpersoalan di atas adalah dengan menggunakan model pembelajaran inkuiri terbimbing. Menurut Sanjaya ( 2010: 200) inkuiri terbimbing adalah sebagai proses pembelajaran dimana guru menyediakan unsur-unsur asas dalam satu pelajaran dan kemudian meminta pelajar membuat generalisasi. Meidawati (2014: 5) mengungkapkan model pembelajaran inkuiri terbimbing merupakan model pembelajaran yang diorganisasikan lebih terstruktur, di mana guru mengendalikan keseluruhan proses-proses interaksi dan menjelaskan prosedur penelitian yang harus dilakukan oleh siswa.

Model inkuiri terbimbing merupakan model pembelajaran yang berupaya untuk menanamkan dasar-dasar berpikir ilmiah pada siswa, sehingga siswa lebih banyak belajar sendiri dan mampu mengembangkan kreativitasnya dalam memecahkan masalah (Fathurrohman, 2015). Hal ini disimpulkan oleh Sukmawati, bahwa model pembelajaran inkuiri terbimbing adalah salah satu model yang melibatkan keaktifan siswa dalam mengeksplorasi dan menemukan sendiri pengetahuan mereka (Sukmawati, 2014: 203).

\section{METODE PENELITIAN}

Jenis penelitian ini adalah penelitian eksperimen, dengan perlakuan model pembelajaran model inkuiri terbimbing pada siswa kelas eksperimen. Sedangkan kelas kontrol diajar dengan menggunakan model pembelajaran konvensional.

Penelitian ini dilaksanakan di SMP Negeri 8 Kendari tahun ajaran 2017/2018 yang terletak di jalan Imam Bonjol Kelurahan Wawombalata. Waktu penelitian dilaksanakan bulan 17 Oktober - 9 November 2017. Populasi dalam penelitian ini adalah seluruh siswa kelas
Model pembelajaran inkuiri memberikan kesempatan kepada siswa untuk mempelajari cara menemukan fakta, konsep dan prinsip melalui pengalamannya secara langsung. Jadi, siswa bukan hanya belajar dengan membaca kemudian menghafal materi pelajarannya, tetapi juga mendapatkan kesempatan untuk berlatih mengembangkan keterampilan berpikir dan bersikap ilmiah sehingga memungkinkan terjadinya proses konstruksi pengetahuan dengan baik sehingga siswa akan dapat meningkatkan pemahamannya pada materi yang dipelajari (Wayan, 2010: 5).

Model pembelajaran inkuiri terbimbing yang dimaksud dalam penelitian ini adalah pembelajaran yang membuat siswa untuk bisa mencari dan menyelidiki suatu masalah dengan cara yang sistematis, kritis, dan logis dalam menemukan konsep, fakta dan prinsip yang diberikan guru melalui pengalamannya secara langsung dengan langkah-langkah Planning (perencanaan), Retrieving (mendapatkan informasi), Processing (memproses informasi), Creating (menciptakan informasi), Sharing (mengkomunikasikan informasi), Evaluating (mengevaluasi).

VIII SMP Negeri 8 Kendari yang terdiri dari 1 kelas khusus dan 6 kelas paralel yang terdaftar pada tahun ajaran 2017/2018. Penentuan sampel dalam penelitian menggunakan teknik purposive sampling. Dalam hal ini, dipilih dua kelas berbeda yang mempunyai rata-rata kemampuan yang relatif sama dengan memperhatikan rata-rata dan varians hasil tes. Dua kelas yang dipilih adalah kelas VIII2 dan kelas VIII4. Pemilihan kelas eksperimen dan kelas kontrol, dilakukan secara random. Hasilnya, kelas VIII4 
sebagai kelas eksperimen dan kelas VIII2 sebagai kelas kontrol. pada Tabel 1 .

Desain penelitian ini ditunjukkan

Tabel 1. Desain Penelitian

\begin{tabular}{lcc}
\hline Kelompok & Treatmen & Posttest \\
\hline Eksperimen & $\mathrm{T}_{1}$ & $\mathrm{X}_{1}$ \\
Kontrol & $\mathrm{T}_{2}$ & $\mathrm{X}_{2}$ \\
\hline
\end{tabular}

(Sugiyono, 2016: 114)

Keterangan :

$\mathrm{T}_{1}=$ Perlakuan dengan model pembelajaran inkuiri terbimbing.

$\mathrm{T}_{2}=$ Perlakuan dengan model pembelajaran konvensional.

$\mathrm{X}_{1}=$ Hasil Posttest Kelas Eksperimen.

$\mathrm{X}_{2}=$ Hasil Posttest Kelas Kontrol.

Penelitian ini dilakukanlah pengujian hipotesis (uji-t) dengan terlebih dahulu dilakukan uji syarat normalitas dan homogenitas data. Hasil dari uji normalitas di peroleh bahwa kedua kelas berdistribusi normal dan hasil dari uji homogenitas diperoleh bahwa kedua kelas memiliki varians yang homogen. Untuk mengetahui perbandingan penggunaan model pembelajaran inkuiri terbimbing dan model pembelajaran konvensional terhadap kemampuan literasi matematis siswa, digunakan uji t sampel independen dengan bantuan SPSS 21. Langkah langkah pengujiannya adalah sebagai berikut:

1. Memasukkan data ke data editor dengan mendefinisikan variabel pada variabel view. Variabel 1 definisikan sebagai data posttest dan variabel 2 definisikan sebagai kelompok. Pada bagian value labels, definisikan kelompok 1 sebagai kelas eksperimen dan kelompok 2 sebagai kelas kontrol.

2. Pilih menu analyze kemudian pilih compare means lalu pilih independent sample t test.

3. Akan tampak kotak dialog independent sample $T$ test. Masukkan variabel posttest ke kotak Test Variable(s) dan variabel kelompok ke kotak Grouping Variables.

4. Klik Define Groups akan muncul kotak dialog define groups. Masukkan kode 1 untuk group 1 dan kode 2 untuk group 2. Lalu klik continue.

5. Berikutnya akan muncul lagi kotak dialog independent - samples $T$ test : option. Klik options, sehingga muncul kotak dialog options. Karena menggunakan alfa 0,05 maka tingkat kepercayaan yang digunakan adalah $95 \%$. Klik continue lalu $O K$.

Kriteria pengambilan keputusan adalah jika nilai Sig. lebih besar dari 0,05 maka $\mathrm{H}_{0}$ diterima. Artinya, kemampuan literasi matematis siswa yang diajar dengan model pembelajaran inkuiri terbimbing tidak berbeda signifikan dengan kemampuan literasi matematis siswa yang diajar dengan model pembelajaran konvensional. Jika nilai Sig. lebih kecil dari 0,05 maka $\mathrm{H}_{0}$ ditolak. Artinya, kemampuan literasi matematis siswa yang diajar dengan model pembelajaran inkuiri terbimbing lebih tinggi secara signifikan dibandingkan dengan kemampuan literasi matematis siswa yang diajar dengan model pembelajaran konvensional.

\section{HASIL PENELITIAN}


Hasil analisis deskriptif statistik matematis siswa dapat dilihat pada Tabel 2 terhadap tes kemampuan literasi berikut.

Tabel 2. Statistik Deskriptif Kemempuan Literasi Matematis Siswa Kelas Eksperimen dan Kelas Kontrol

\begin{tabular}{lcccccr}
\hline & \multicolumn{7}{c}{ Descriptive Statistics } & & \\
& N & Min & Max & Mean & $\begin{array}{c}\text { Std. } \\
\text { Deviation }\end{array}$ & Variance \\
\hline $\begin{array}{l}\text { Hasil_Kemampuan_Literasi } \\
\text { _K_Eksperiman }\end{array}$ & 21 & 21 & 82 & 53.06 & 15.90 & 252.93 \\
$\begin{array}{l}\text { Hasil_Kemampuan_Literasi } \\
\text { _K_Kontrol }\end{array}$ & 23 & 18 & 79 & 46.89 & 14.69 & 216.05 \\
Valid N (listwise) & 21 & & & & & \\
\hline
\end{tabular}

Berdasarkan hasil analisis Tabel 2 diatas terlihat bahwa rata-rata kemampuaan literasi matematis siswa yang diajar dengan model pembelajaran inkuiri terbimbing sebesar 53,06 ini lebih tinggi dibandingkan dengan yang diajar dengan model pembelajaran konvensioanal sebesar 46,89. Nilai maksimum posttest pada kelas eksperimen sebesar 82 sedangkan pada kelas kontrol sebsar 79. Begitupun dengan nilai minimumnya, yaitu nilai 21 pada kelas eksperimen dan 18 pada kelas kontrol. Nilai standar deviasi (Std. Deviation) untuk kelas eksperimen adalah 15,90 dan untuk kelas kontrol adalah 14,69. Sedangkan nilai varians adalah kuadrat dari nilai standar deviasi, yaitu nilai 252,93 pada kelas eksperimen dan nilai 216,05 pada kelas kontrol.

Hasil analisis inferensial kemampuan literasi matematis siswa menunjukkan bahwa data kemampuan literasi matematis siswa kelas eksperimen dan kelas kontrol berdistribusi normal dan homogen. Selanjutnya, akan digunakan uji t sampel independen untuk mengetahui kemampuan literasi matematis siswa kelas eksperimen yang diajar menggunakan model inkuiri terbimbing dibandingkan dengan siswa kelas kontrol yang diajar menggunakan pembelajaran konvensional .

Hasil pengujian hipotesis dapat dilihat pada Tabel 3 .

Tabel 3. Hasil Uji T Sampel Independen Kemampuan Literasi Siswa

\begin{tabular}{|c|c|c|c|c|c|c|}
\hline \multicolumn{7}{|c|}{ Independent Samples Test } \\
\hline & & \multicolumn{2}{|c|}{$\begin{array}{c}\text { Levene's Test for } \\
\text { Equality of } \\
\text { Variances }\end{array}$} & \multicolumn{3}{|c|}{$\begin{array}{c}\text { t-test for Equality of } \\
\text { Means }\end{array}$} \\
\hline & & $\mathbf{F}$ & Sig. & $\mathbf{t}$ & df & $\begin{array}{l}\text { Sig. } \\
\text { (2-tailed) }\end{array}$ \\
\hline $\begin{array}{l}\text { Hasil } \\
\text { Kemampuan }\end{array}$ & $\begin{array}{l}\text { Equal variances } \\
\text { assumed }\end{array}$ & .11 & 0.737 & 1.33 & 42 & 0.189 \\
\hline $\begin{array}{l}\text { Literasi } \\
\text { Matematis }\end{array}$ & $\begin{array}{l}\text { Equal variances } \\
\text { not assumed }\end{array}$ & & & 1.33 & 40.8 & 0.19 \\
\hline
\end{tabular}


Berdasarkan Tabel 3, nilai Sig. = 0,189 dalam hal ini Sig. > 0,05, sehingga keputusannya adalah terima $\mathrm{H}_{0}$. Berdasarkan nilai $t_{\text {hitung }}=1,33<1,683=$ $t_{\text {tabel }}$ juga mengakibatkan $\mathrm{H}_{0}$ diterima. Karena $\mathrm{H}_{0}$ diterima, maka dapat disimpulkan bahwa kemampuan literasi

\section{PEMBAHASAN}

Penelitian ini dilaksanakan sebanyak lima kali pertemuan pada kelas eksperimen dan kelas kontrol, dengan empat kali pertemuan digunakan proses pembelajaran dan satu kali pertemuan digunakan untuk tes kemampuan literasi matematis. Tes kemampuan literasi ini digunakan untuk mengukur kemampuan literasi matematis kelas eksperimen dan kelas kontrol setelah diadakan perlakuan pada kedua kelas tersebut.

Proses pembelajaran di kelas eksperimen mula-mula diawali dengan kegiatan pendahuluan seperti guru membuka pelajaran dengan salam dan berdoa, mengecek kehadiran siswa, memotivasi pentinganya memahami materi persamaan garis, menyampaikan tujuan pembelajaran, pokok-pokok materi yang akan dipelajari dengan alur model pembelajaran inkuiri terbimbing dan membagi siswa kelompok belajar dengan anggota 5-6 siswa dalam satu kelompok. Kemudian pada setiap siswa diberikan bahan ajar dan LKS untuk dikerjakan secara berkelompok. Pada tahap ini, siswa diberikan pengarahan dan bimbingan melalui penjelasan atau pertanyaan yang mengarah pada penyelesaian masalah. Setelah semua kelompok telah mengerjakan LKS yang diberikan sesuai dengan waktu yang ditetapkan, beberapa siswa dipilih mewakili kelompoknya tampil di depan kelas untuk mempresentasekan hasil kerja kelompoknya untuk ditanggapi oleh kelompok lain. Jika ada jawaban siswa yang keliru maka diberikan bantuan untuk mengambil kesimpulan alternatif jawaban yang benar dari hasil pemecahan masalah matematis siswa yang diajar dengan model pembelajaran inkuiri terbimbing tidak berbeda signifikan dengan kemampuan literasi matematis siswa yang diajar dengan model pembelajaran konvensional.

yang dibuat masing-masing kelompok. Diakhir pertemuan, siswa membuat kesimpulan dari materi yang telah dipelajari. Kemudian diberikan tes evaluasi berupa lembar penilaian 1 (LP 1) yang dikerjakan secara individu dan ditutup dengan pemberian tugas yang dikerjakan di rumah.

Berdasarkan hasil uji hipotesis untuk melihat perbedaan perbandingan kemampuan literasi matematis siswa yang diajar dengan model pembelajaran inkuiri terbimbing dan model pembelajaran konvensional, diperoleh bahwa kemampuan literasi matematis siswa yang diajar dengan model pembelajaran inkuiri terbimbing tidak berbeda signifikan dengan kemampuan literasi matematis siswa yang diajar dengan model pembelajaran konvensional. Hal ini didasarkan $\mathrm{t}_{\text {hitung }}=1,337<1,683=\mathrm{t}_{\text {tabel }}$ sehingga keputusannya adalah terima $\mathrm{H}_{0}$. Dengan diterimanya $\mathrm{H}_{0}$, maka penelitian ini menyimpulkan bahwa kemampuan literasi matematis siswa yang diajar dengan model pembelajaran inkuiri terbimbing tidak berbeda signifikan dengan kemampuan literasi matematis siswa yang diajar dengan model pembelajaran konvensional.

Penulis menyadari, masih banyak kekurangan yang menyebabkan hal ini terjadi. Pada pandangan penulis, model pembelajaran inkuiri tebimbing ini, diduga lebih baik dalam hal meningkatan kemampuan literasi matematis siswa dibandingkan dengan model pembelajaran konvensional. Namun disadari atau tidak, alokasi waktu 4 kali pertemuan rasanya belum cukup agar menjadikan penerapan 
model pembelajaran inkuiri terbimbing ini menjadi lebih baik dan efektif. Kendala utama dihadapi guru pada penelitian ini adalah siswa baru mengalami pembelajaran dengan model pembelajaran inkuiri terbimbing. Hal ini dapat dilihat dari persentase keaktifitan siswa pada model pembelajaran inkuiri terbimbing. Dari pertemuan pertama sampai pertemuan keempat keaktifan siswa tidak pernah mencapai persentase $100 \%$.

Penulis percaya bahwa penelitian ini, tidaklah gagal. Berdasar pada apa yang penulis kemukakan di atas, penulis sangat senang terhadap antusias siswasiswa di dalam proses pembelajaran. Ditambah lagi walaupun pembelajaran dengan model pembelajaran inkuiri terbimbing adalah hal baru, mereka mampu memperoleh hasil yang walaupun terus terang tidak terkategori baik, namun telah mengimbangi bahkan melebihi ratarata perolehan hasil tes pada kelas yang pembelajarannya menggunakan model pembelajaran konvensional yang telah digunakan selama ini.

Berdasarkan teori dan penelitian yang relevan, model pembelajaran inkuiri terbimbing seharusnya lebih baik dan lebih efektif diterapkan terhadap kemampuan literasi matematis siswa dibandingkan dengan model pembelajaran yang diterapkan di sekolah selama ini yaitu model pembelajaran konvensional. Namun pada penelitian ini, justru menyimpulkan bahwa kemampuan literasi matematis siswa yang diajar dengan model pembelajaran inkuiri terbimbing tidak berbeda signifikan dengan kemampuan literasi matematis siswa yang diajar dengan model pembelajaran konvensional.

Terdapat beberapa faktor yang mempengaruhi hasil penelitian ini. Selain keadaan nyata yang peneliti hadapi seperti dikemukakan di atas, dipertegas bahwa faktor yang menjadi perhatian peneliti adalah proses pembelajaran dengan menggunakan model pembelajaran yang dilakukan sebanyak 4 kali pertemuan. Model pembelajaran baru yang diterapkan sebanyak 4 kali pertemuan tentu belum efektif untuk memberikan hasil yang maksimal. Langkah-langkah pembelajaran yang berbeda dengan pembelajaran yang biasanya jelas menuntut pembiasaan perubahan perilaku, baik bagi siswa dalam belajar maupun guru dalam mengajar. Hal ini sesuai yang dikemukakan oleh Hosnan (2016) bahwa salah satu kekurangan model pembelajaran inkuiri terbimbing adalah dalam mengimplementasikan model pembelajaran inkuiri terbimbing memerlukan waktu yang panjang sehingga sering pendidik sulit menyesuaikannya dengan waktu yang telah ditentukan.

Adaptasi yang dilakukan sebanyak 4 kali pertemuan tidak menjamin ketercapaian keterlaksanaan pembelajaran yang optimal dan efektif. Hal ini terbukti dengan hasil observasi guru dalam pelaksanaan pembelajaran menggunakan model pembelajaran inkuiri terbimbing yang tidak selalu mencapai $100 \%$. Kemudian, adaptasi siswa terhadap model pembelajaran inkuiri terbimbing pun demikian. Siswa masih sulit membiasakan diri untuk bertingkah laku sesuai dengan langkah-langkah pembelajaran dengan menggunakan model pembelajaran inkuiri terbimbing. Hal ini terbukti dengan hasil pengamatan aktivitas siswa saat pembelajaran dengan menggunakan model pembelelajaran inkuiri terbimbing tidak begitu baik. Bahkan, tidak ada pertemuan yang persentase keaktifan siswa yang mencapai $100 \%$, dengan hasil ini jelas menunjukkan ketercapaian yang tidak maksimal.

Selain faktor tersebut, ketidaksesuaian antara teori dan hasil penelitian relevan yang sudah pernah dilaksanakan dengan penelitian ini tentu disebabkan juga oleh keterbatasan guru dalam mengelolah model pembelajaran yang digunakan. Dalam hal ini adalah 
model pembelajaran inkuiri terbimbing. Keterbatasan dalam mengelola pembelajaran ini meliputi keterbatasan dalam mengelola kelompok dalam kelas, keterbatasan dalam mengkondisikan kelas agar pelaksanaan pembelajaran berlangsung menyenangkan bagi siswa dan keterbatasan dalam menyusun lembar kerja siswa agar sesuai dengan tujuan model pembelajaran inkuiri terbimbing dan dalam pelaksanaan penelitian soalsoal tes kemampuan literasi matematis

\section{KESIMPULAN DAN SARAN}

Berdasarkan hasil penelitian dan pembahasan, maka dapat ditarik kesimpulan bahwa kemampuan literasi matematis siswa yang diajar dengan model pembelajaran inkuiri terbimbing tidak berbeda signifikan dengan kemampuan literasi matematis siswa yang diajar dengan model pembelajaran konvensional. Hal ini didasarkan $t_{\text {hitung }}=1,337<1,683=$ $\mathrm{t}_{\text {tabel }}$

Berdasarkan kesimpulan yang diperoleh dalam penelitian ini, maka peneliti memberikan saran-saran sebagai berikut:

1. Model pembelajaran inkuiri terbimbing sebaikanya dilaksanakan secara berkesinambungan untuk memperoleh hasil yang maksimal. Tetapi adakalanya harus memperhatikan materi pembelajaran yang sesuai dengan model pembelajaran inkuir

\section{DAFTAR PUSTAKA}

Arikunto, S. 2015, Prosedur Penelitian Suatu Pendekatan Praktik, RinekaCipta: Yogyakarta. .2016, Dasar-Dasar Evaluasi Pendidikan. Jakarta: Bumi Aksara.

BSNP. 2006, Standar Kompetensi dan Kompetensi Dasar. Matematika Sekolah Dasar dan Menengah, Badan Standar Nasional Pendidikan, Jakarta. siswa hanya diberikan pada LKS pertemuan terakhir, yang seharusnya setiap akhir pertemuan pembelajaran soalsoal kemampuan literasi matematis siswa diberikan kepada siswa untuk memberikan hasil yang baik.

Meskipun demikian, jika di bandingkan dengan data kemampuan literasi matematis sebelum penelitian ini, hasil penelitian ini telah menunjukan peningkatan kemampuan literasi matematis siswa yang lebih baik.

tebimbing, karena tidak semua materi cocok diajarkan dengan model pembelajaran inkuiri terbimbing dan hanya materi yang membutukan penanaman konsep yang sesuai dengan model pembelajaran inkuiri terbimbing.

2. Untuk peneliti yang ingin melakukan penelitian sejenis, langkah-langkah pembelajaran dengan dengan model pembelajaran inkuiri terbimbing sebaiknya dipahami secara maksimal, agar keterlaksanaan pembelajarannya nanti bisa lebih maksimal.

3. Soal-soal tentang kemampuan literasi matematis harus diberikan setelah setiap pertemuan berakhir, hal ini didasarkan agar siswa terbiasa mengerjakan soal-soal literasi, dengan harapan dapat meningkatkan kemampuan literasi mereka.

Fathurrohman, M. 2015, Model-Model Pembelajaran Inovatif. Yogyakarta: Ar-Ruzz Media.

Gurria, A. 2015, PISA 2015 Results in Focus. [Online]. Tersedia: https://www.oecd.org/pisa/pisa2015-results-in-focus.pdf. $[06$ Agustus 2017].

Jihad, A. \& Haris, A. 2012, "Evaluasi Pembelajaran". Yogyakarta: Multi Pressindo. 
Johar, R. 2012, Domain Soal Pisa Untuk Literasi Matematika, Jurnal Peluang Pendidikan Matematika Unsyiah, 1 (1) : 8-10.

Meidawati. 2014, Pengaruh Model Pembelajaran Inkuiri Terbimbing Terhadap Peningkatan Kemampuan Pemecahan Masalah Matematis Siswa SMP. Jurnal Pendidikan dan Keguruan. 1(2) : 1-10.

OECD. 2010, Mathematics Framework: Draft Subject to Possible revision after the Field Trial PISA 2012. [Online]. Tersedia: www.oecd.org. [5 September 2017]

2013, Literacy Skills for the World of Tomorrow-Further Results from PISA 2000. Organisation for Economic Co-operation \& Development \& Unesco Institute for Statistics.

Sanjaya, W. 2010, Strategi Pembelajaran. Jakarta: Kencana Prenada Media Grup.

Setiawan, H., Dafik, \& Srilestari, N.D. 2014, "Soal Matematika dalam PISA Kaitannya dengan Literasi Matematika dan Keterampilan Berpikir Tingkat Tinggi”, Prosiding Seminar Nasional Matematika. Universitas Jember.

Sugiyono 2014. Metod Penelitian Kuantitatif , Kualitatif dan $R \& D$. Bandung: Alfabeta.

Kuantitatif, $\begin{gathered}\text { Metode Penelitian } \\ \text { kualitatif, dan } \\ \text { Kombinasi. Bandung: Alfabeta. }\end{gathered}$
.........2016.

Sukmawati, A. \& Puri, L.S. 2014, "Penerapan Model Inkuiri Terbimbing dalam Pembelajaran Matematika untuk Meningkatkan Kemampuan Penalaran Matematis Siswa SMK", Jurnal Pendidikan Matematika, 2 (3): 202-210.
Wayan, I. 2012, Pengaruh Model Pembelajran Inkuiri Terbimbing Berbasis Assesment Portofolio terhadap Hasil Belajar Kimia Siswa Kelas X Ditinjau dari Adversity Quotient. Jurnal Penelitian Pasca Sarjana. Undiksha, Bali. 